JURNAL RISET MAHASISWA AKUNTANSI

http://ejournal.unikama.ac.id/index.php/jrma

JRMA, Volume 6, No 1, April 2018

\title{
PENGARUH KOMPENTENSI SUMBER DAYA MANUSIA ,PENERAPAN SISTEM AKUNTANSI DAERAH DAN PEMANFAATAN TEKNOLOGI INFORMASI TERHADAP KUALITAS LAPORAN KEUANGAN PEMERINTAH DAERAH (STUDI PADA SKPD KABUPATEN LUMAJANG)
}

\author{
MAIMUNAH \\ e-mail:Meimunah1811@gmail,com
}

\author{
Anwar made \\ Supami wahyu \\ (Program studi akuntansi , fakultas ekonomika dan bisnis, universitas kanjuruhan malang)
}

\begin{abstract}
Abstrak
Penelitian ini bertujuan untuk menganalisis pengaruh kompetensi sumber dayamanusia, penerapan sistem akuntansi daerah, penerapa dan pemanfaatan teknologi informasi terhadap kualitas laporankeuangan pemerintah daerah secara parsial maupun simultan. dalam penelitian ini, sample yang diambil adalah 59 orang dari 9 satuan kerja perangkat daerah (SKPD) yang terdiri dari sub bagian keuangan beserta staf bagian akuntansi . pengumpulan data di lakukan melaluli observasi langsung dan survei yang diperoleh dengan cara pembagian kuesioner kepada para responden. penelitian ini menggunakan metode penelitian kuantitatif hasil penelitian pertama menunjukkan bahwa kompentensi sumber daya manusia, dan pemanfaatan teknologi informasi berpengaruh positif dan singnifikan terhadap kualitas laporan keuangan pemerintah daerah sedangkan penerapan sistem akuntansi daerah tidak berpengaruh terhadap kualitas laporan keuangan daerah kabupaten lumajang . kedua secara simultan kompentensi sumber daya manusia, penerapan sistem akuntansi daerah dan pemanfaatan teknologi informasi berpengaruh positif dan singnifikan terhadap kualitas laporan keuangan pemerintah daerah kabupaten lumajang.
\end{abstract}

Kata kunci: kompetensi sumber daya manusia, penerapan sistem akuntansi daerah dan pemanfaatan teknologi informasi dan kualitas laporan keuangan.

\begin{abstract}
This study aims to analyze the influence of human resource competencies, the application of regional accounting systems, the adoption and utilization of information technology on the quality of financial reports of local governments partially or simultaneously. in this study, the sample taken was 59 people from 9 regional work units (SKPD) consisting of financial sub-departments and accounting staff. Data collection is done through direct observation and surveys obtained by distributing questionnaires to the respondents. This research uses quantitative research methods. The results of the first research show that the competence of human resources, and the use of information technology have a positive and significant effect on the quality of the financial statements of the local government while the application of the regional accounting system does not affect the quality of the financial statements of the Lumajang regency. the competency of human resources simultaneously, the application of the regional accounting
\end{abstract}


Maimunah, Pengaruh Kompentensi Sumber Daya Manusia ,Penerapan Sistem Akuntansi Daerah Dan Pemanfaatan Teknologi Informasi Terhadap Kualitas Laporan Keuangan Pemerintah Daerah (Studi Pada SKPD Kabupaten Lumajang)

system and the use of information technology have a positive and significant effect on the quality of the financial statements of the Lumajang district government.

Keynotes: human resource competencies, regional accounting systems, information technology and quality of financial reports.

\section{A. PENDAHULUAN}

Organisasi sektor publik di Indonesia dalam praktiknya kini diwarnai dengan munculnya fenomena menguatnya tuntutan akuntabilitas atas organisasi-organisasi publik tersebut, baik di pusat maupun daerah. Akuntabilitas merupakan bentuk kewajiban mempertanggungjawabkan keberhasilan atau kegagalan pelaksanaan misi organisasi dalam mencapai tujuan dan sasaran yang telah ditetapkan sebelumnya, melalui suatu media pertanggungjawaban yang dilaksanakan secara periodik (Stanbury, 2003 dalam Mardiasmo, 2006).

Di era reformasi ini, terselenggaranya pemerintahan yang baik merupakanprasyarat bagi setiap pemerintahan untuk mewujudkan tujuan serta citacita bangsa bernegara. Tidak hanya di pemerintah pusat, pemerintah daerah pun diharapkan dapat mewujudkan kinerja yang baik. Dalam mewujudkan kinerja pemerintah daerah yang baik, pemerintah daerah harus terus melakukan upaya perbaikan dalam laporan keuangan. Laporan keuangan yang berkualitas tentunya dapat berguna bagi para pengguna atau stakeholder, terutama transparansi kepada masyarakat.

Laporan keuangan merupakan media bagi sebuah entitas, dalam hal ini pemerintah daerah untuk mempertanggungjawabkan kinerja keuangannya kepada publik. Pemerintah daerah harus mampu menyajikan laporan keuangan yang mengandung informasi keuangan yang berkualitas. Terdapat empat karakteristik kualitas laporan keuangan menurut Undang-Undang No. 71 tahun 2010 tentang Standar Akuntansi Keuangan. Karakteristik tersebut yaitu relevan, andal, dapat dibandingkan, dan dapat dipahami.

Pelaporan Peuangan pemerintah di Indonesia merupakan sesuatu hal yang menarik untuk dikaji lebih lanjut. Dasar pemikiran ini berasal dari fakta bahwa masih terdapat banyak laporan keuangan yang belum mendapatkan opini Wajar Tanpa Pengecualian (WTP). Menurut Winidyaningrum dan Rahmawati (2010) kenyataannya di dalam laporan keuangan pemerintah masih banyak disajikan data-data yang tidak sesuai. Selain itu juga masih banyak penyimpangan-penyimpangan yang berhasil ditemukan oleh Badan Pemeriksa Keuangan (BPK) dalam pelaksanaan audit laporan keuangan pemerintah

Dalam suatu pemerintahan, tentunya membutuhkan sumber daya manusia yang handal dan berkompeten guna memperoleh laporan keuangan pemerintahan yang berkualitas. Menurut Mardiasmo (2002: 146), sumber daya manusia telah memiliki pengetahuan dan pemahaman mengenai hal-hal yang harus dikerjakan, sehingga laporan keuangan yang disusun dapat diselesaikan dan disajikan tepat pada waktunya. Semakin cepat laporan keuangan disajikan maka akan semakin baik dalam hal pengambilan keputusan.

Tujuan laporan keuangan adalah menyediakan informasi yang menyangkut posisi keuangan, kinerja, serta perubahan posisi keuangan suatu perusahaan yang 
Maimunah, Pengaruh Kompentensi Sumber Daya Manusia ,Penerapan Sistem Akuntansi Daerah Dan Pemanfaatan Teknologi Informasi Terhadap Kualitas Laporan Keuangan Pemerintah Daerah (Studi Pada SKPD Kabupaten Lumajang)

bermanfaat bagi sejumlah besar pemakai dalam pengambilan keputusan. Namun demikian, laporan keuangan tidak menyediakan semua informasi yang mungkin dibutuhkan pemakain dalam mengambil keputusan ekonomi karena secara umum menggambarkan pengaruh keuangan dan kejadian masa lalu, dan tidak diwajibkan untuk menyediakan informasi.

Pemanfaatan teknologi informasi oleh Pemerintah dan Pemerintah Daerah diatur dalam Peraturan pemerintah No 5 tahun 2013.Pemanfaatan teknologi informasi dan komunikasi dalam penyelengaraan pemerintah bertujuan sebagai petunjuk teknis dan standar bagi SKPD di lingkungan pemerintah daerah dalam pembangunan, pengelolaan, monitoring dan evaluasi teknologi informasi dan komunikasi yang komprehensif, efesien dan efektif.

\section{B. Pengembangan Hipotesis}

\section{Pengaruh kompetensi sumber daya manusia terhadap kualitas laporan keuangan} pemerintah daerah

SDM merupakan human capital di dalam organisasi. Human capital merupakan pengetahuan, keterampilan, dan kemampuan seseorang yang dapat digunakan untuk menghasilkan layanan profesional dan economic rent. Human capital merupakan sumber inovasi dan gagasan. Karyawan dengan human capital tinggi lebih memungkinkan untuk memberikan layanan yang konsisten danberkompetensi tinggi (Sugeng dan Imam, 2000 dalam Sutaryo, 2011).

\section{Pengaruh penerapan Sistem Akuntansi Keuangan Daerah(SAKD) terhadap} kualitas laporan keuangan daerah.

Sistem informasi akuntansi dirancang untuk mempermudah setiapentitas dalam menyusun laporan keuangan.untuk menghasilkan laporankeuangan tersebut diperlukan suatu sistem akuntansi keuangan daerah yangdidasarkan atas standar akuntansi pemerintah. Dengan bantuan sisteminformasi akuntansi akan memberikan manfaat yaitu:

a. Menyediakan informasi yang akurat dan tepat waktu sehingga dapat melakukan aktivitas utama pada value chain secara efektif dan efisien

b. Meningkatkan efisiensi

c. Meningkatkan kemampuan dalam mengambil keputusan

d. Meningkatkan sharing knowledge

e. Menambah efisiensi kerja pada bagian keuangan.

3.Pengaruh pemanfaatan teknologi informasi terhadap kualitas laporan keuangan pemerintah daerah

Perkembangan teknologi informasi tidak hanya dimanfaatkan pada organisasi bisnis tetapi juga pada organisasi sektor publik, termasuk pemerintahan. Dalam penjelasan Peraturan Pemerintah No. 56 Tahun 2005 tentang Sistem Informasi Keuangan Daerah disebutkan bahwa untuk menindaklanjuti terselenggaranya proses pembangunan yang sejalan dengan prinsip tata kelola pemerintahan yang baik (Good Governance), pemerintah, dan pemerintah daerah berkewajiban untuk mengembangkan dan memanfaatkan kemajuan teknologi informasi untuk meningkatkan kemampuan mengelola keuangan daerah, dan menyalurkan informasi keuangan daerah kepada pelayanan publik. Pemerintah perlu mengoptimalisasi pemanfaatan kemajuan teknologi informasi untuk membangun jaringan sistem 
Maimunah, Pengaruh Kompentensi Sumber Daya Manusia ,Penerapan Sistem Akuntansi Daerah Dan Pemanfaatan Teknologi Informasi Terhadap Kualitas Laporan Keuangan Pemerintah Daerah (Studi Pada SKPD Kabupaten Lumajang)

informasi manajemen dan proses kerja yang memungkinkan pemerintahan bekerja secara terpadu dengan menyederhanakan akses antar unit kerja.

\section{METODE PENELITIAN}

\section{1. ruang lingkup penelitian}

Penelitian membuat ruang lingkup penelitian untuk membatasi cakupan peneliti supaya tidak melenceng dari pokok permasalahan yang akan di teliti, penelitian ini di lakukan pada SKDP ( satuan kerja perangkat daerah ) yang ada di lingkungan Kabupaten Lumajang

\section{Populasi dan Sampel}

- Populasi

Populasi adalah wilayah generalisasi yang terdiri dari objek atau subjek yang akan menjadi kuantitas dan karakteristik tertentu yang ditetapkan oleh penelitian untuk dipelajari dan kemudian ditarik kesimpulannya (Sugiono, 2002). Populasi dalam penelitian ini adalah pengelola unit kerja atau pejabat struktural pada Satuan Kerja Perangkat Daerah Kabupaten Lumajang yang terdiridariBadan, Dinas, dan Kantor Kecamatan.

\section{- Sampel}

Sampel adalah bagian dari populasi (sebagian atau wakil populasi yang diteliti). Pengambilan sampel atas responden dilakukan secara purposive sampling. Purposive sampling digunakan karena informasi yang akan diambil berasal dari sumber yang sengaja dipilih berdasarkan kriteria yang telah ditetapkan peneliti (Sekaran, 2003)

\section{3. jenis dan sumber data}

jenis data yang di gunakan dalam penelitian ini adalah data kuantitatif dimana data berupa respon atau pertanyaan ( jawaban respon ) di kuantitatifkan dengan skor . sumber data penelitian yang akan di lakukan ini menggunakan data primer dengan metode survei, yaitu sumber data penelitian yang di peroleh secara langsung dari sumber asli . data untuk penelitian ini di peroleh dengan menyebarkan kuesioner kepada responden pada lokasi penelitian yang di tetapkan

\section{Definisi Operasional Variabel}

\section{- Kompetensi Sumber daya Manusia (SDM)}

Sumber Daya Manusia (SDM) merupakan potensi yang terkandung dalam diri manusia untuk mewujudkan peranannya sebagai manusia yang adaptif dan transformatif yang mampu mengelola dirinya sendiri serta seluruh potensi yang terkandung di alam menuju tercapainya kesejahteraan kehidupan dalam tatanan yang seimbang dan berkelanjutan.

\section{- Penerapan Sistem Akuntansi Keuangan Daerah}

Sistem akuntansi keuangan secara sederhana adalah suatu sistem informasi yang menggabungkan proses pencatatan, pengklasifikasian, pengikhtisaran, pelaporan data yang berkaitan dengan keuangan dari suatu entitas sehingga dapat menghasilkan informasi keuangan yang dapat digunakan sebagai dasar dalam pengambilan keputusan oleh pihak-pihak yang berkepentingan.

\section{- Pemanfaatan Teknologi Informasi}

Pemanfaatan teknologi informasi merupakan penggunaan secara optimal dari komputer (mainframe, mini, micro), perangkat lunak (software), database, jaringan (internet, intranet), electronic commerce, dan jenis lainnya yang berhubungan dengan 
Maimunah, Pengaruh Kompentensi Sumber Daya Manusia ,Penerapan Sistem Akuntansi Daerah Dan Pemanfaatan Teknologi Informasi Terhadap Kualitas Laporan Keuangan Pemerintah Daerah (Studi Pada SKPD Kabupaten Lumajang)

teknologi. Pemanfaatan teknologi informasi mencakup adanya pengolahan data, pengolahan informasi, sistem manajemen dan proses kerja secara elektronik dan pemanfaatan kemajuan teknologi informasi agar pelayanan publik dapat diakses secara mudah dan murah oleh masyarakat (Hamzah, 2009).

- Kualitas Laporan Keuangan Pemerintah Daerah

Kualitas laporan keuangan pemerintah daerah merupakan ukuran - ukuran normatif yang perlu diwujudkan dalam informasi akutansi sehingga dapat memenuhi tujuannya.

Adapun beberapa indikator dari kualitas laporan keuangan pemerintah daerah:

1) Relevan

2) Handal

3) Dapat dibandingkan

4) Dapat dipahami

a. Instrumen Penelitian

Instrumen yang digunakan dalam penelitian ini adalah kuesioner. Pengukuran variabel dilakukan dengan menggunakan skala Likert, dengan skala likert maka variabel yang akan diukur dijabarkan menjadi indikator variabel (Sugiyono, 2007: 107).

\section{Metode Pengumpulan Data}

Jenis data yang digunakan dalam penelitian ini adalah data primer. Survei kuesioner merupakan metode survei dengan menggunakan kuesioner penelitian. Kuesioner adalah satu set pertanyaan yang tersusun secara sistematis dan standar sehingga pertanyaan yang sama dapat diajukan kepada setiap responden. Kuesioner merupakan alat pengumpulan data yang efektif karena dapat diperolehnya data standar yang dapat dipertanggungjawabkan untuk keperluan analisis menyeluruh tentang karakteristik populasi yang diteliti (Supranto, 2000).

\section{Uji Validitas}

Validitas merupakan derajat hingga sejauh mana ketepatan dan ketelitian suatu alat ukur dalam mengukur gejala (Sastradipoera, 2005). Validitas dapat diartikan pula sebagai suatu ukuran yang menunjukkan tingkat-tingkat kevalidan dan kesahihan suatu instrumen. Suatu instrumen yang valid dan sahih mempunyai validitas yang tinggi, yang berarti bahwa alat ukur yang digunakan tersebut sudah tepat. Uji validitas dilakukan dengan cara melihat korelasi skor masing-masing item pernyataan dalam kuesioner dengan skor totalnya. Umar (2002)

\section{Uji Reliabilitas}

Reliabilitas adalah ukuran yang menujukkan bahwa alat ukur yang digunakan dalam penelitian keperilakuan mempunyai keandalan sebagai alat ukur, diantaranya di ukur melalui konsistensi hasil pengukuran dari waktu ke waktu jika fenomena yang diukur tidak berubah (Harrison, dalam Zulganef, 2006).

3. Analisis Statistik Deskriptif

Model yang digunakan untuk menganalisis data adalah dengan cara mendeskripsikan data sampel yang telah terkumpul tanpa membuat kesimpulan yang berlaku umum. Yang bertujuan untuk mengetahui rata-rata (mean)

a. Uji Asumsi Klasik 
Maimunah, Pengaruh Kompentensi Sumber Daya Manusia ,Penerapan Sistem Akuntansi Daerah Dan Pemanfaatan Teknologi Informasi Terhadap Kualitas Laporan Keuangan

Pemerintah Daerah (Studi Pada SKPD Kabupaten Lumajang)

Uji ini dilakukan untuk mengetahui bahwa data yang diolah adalah sah (tidak terdapat penyimpangan) serta distribusi normal, maka data tersebut akan diisi melalui uji asumsi klasik,

\section{b. Uji Normalitas}

Uji normalitas bertujuan untuk menguji apakah dalam regresi, varibel penggangu atau residual memiliki distribusi normal. Seperti diketahui bahwa uji $t$ mengasumsikan bahwa nilai residual mengikuti distribusi normal. Kalau asumsi ini dilanggar maka uji statistik menjadi tidak valid untuk jumlah sampel kecil. Ada dua cara untuk mendeteksi apakah residual berdistribusi normal atau tidak yaitu dengan analisis grafik dan uji statistik (Ghozali, 2005).

\section{b. Uji Multikolinearitas}

Uji multikolonieritas bertujuan untuk menguji apakah model regresi ditemukan adanya korelasi antar variabel bebas (independent).Model regresi yang baik seharusnya tidak terjadi korelasi di antara variabel independen. Jika variabel independen saling berkorelasi, maka variabel -variabel ini tidak ortogonal. Variabel ortogonal adalah variabel independen yang nilai korelasi antar sesama variabel independen sama dengan nol (Ghozali, 2005).

\section{c. Uji Heteroskedastisitas}

Uji heteroskedastisitas bertujuan menguji apakah dalam model regresi terjadi ketidaksamaan variance dari residual satu pengamatan ke pengamatan yang lain. Jika variance dari residual satu pengamatan ke pengamatan lain tetap, maka disebut Homoskesdatisitas dan jika berbeda disebut Heteroskesdatisitas. Model regresi yang baik adalah yang Homoskedastisitas atau tidak terjadi Heteroskesdatisitas (Ghozali, 2005).

\section{Analisis Regresi Linier Berganda}

Analisis regresi linier berganda (multiple regression) dilakukan untuk menguji pengaruh dua atau lebih variabel independen (explanatory) terhadap satu variabel dependen (Ghozali, 2009).

\section{Uji Hipotesis Parsial (Uji-T)}

Uji $t$ pada dasarnya menunjukkan seberapa jauh pengaruh satu variable independen secara individual dalam menerangkan variasi variable independen (ghozali, 2001)

\section{3. koefisiensi determinasi $R^{2}$}

Koefisiensi determinasi $\left(R^{2}\right)$ pada inti nya mengukur seberapa jauh kemampuan model dalam menerangkan variasi variable independen. Nilai koefisien determinasi adalah antara nol dan satu . nilai $R^{2}$ yang kecil berati kemampuan variable -variable independen dalam menjelaskan variasi variable dependen memberikan hampir semua informasi yang di butuhkan untuk memprediksi variasi variable dependen (ghozali, 2001)

\section{Uji Hipotesi Simultan (Uji F)}

Uji hipotesis secara serempak untuk mengetahui pengaruh variable independen secara keseluruhan terhadap variable dependen . uji ini di lakukan dengan membandingkan nilai $F$ hitung denga nilai $F$ tabel . nilai $f$ hitung dari hasil pengelolahan data dengan program SPSS dapat di lihat pada hasil uji analisis regresi linear berganda yaitu tabel ANOVA 
Maimunah, Pengaruh Kompentensi Sumber Daya Manusia ,Penerapan Sistem Akuntansi Daerah Dan Pemanfaatan Teknologi Informasi Terhadap Kualitas Laporan Keuangan Pemerintah Daerah (Studi Pada SKPD Kabupaten Lumajang)

\section{E. HASIL PENELITIAN}

\section{Data Penelitian}

Pengumpulan data pada penelitian ini dilakukan dengan beberapa tahap, yaitu dengan menyebarkan kuesioner kepada responden yang terdiri dari Kasubbag Keuangan dan Staf Bidang Akuntansi di SKPD Kabupaten Lumajang. Dari 65 kuisioner yang dibagikan sebanyak 59 kuesioner yang kembali.

\section{E. ANALISIS DATA DAN UJI HIPOTESIS}

\section{Uji Instrumen Penelitian}

a. Uji Validitas

Uji validitas digunakan untuk menguji sah atau valid tidaknya suatu kuesioner. Pengukuran validitas pada instrumen ini dilakukan dengan korelasi antara butir skor dengan dengan korelasi rtabel. Uji signifikan dilakukan dengan membandingkan nilai rhitung dengan rtabel untuk degree of freedom $(\mathrm{df})=\mathrm{n}-2$, yaitu $(\mathrm{df})=59-2=57$. Bandingkan nilai Correlated Item - Total Correlation tabel pada tingkat signifikan 0,05 dengan nilai sig 2-tailed $=0,000$ sehingga didapatkan rtabel sebesar 0,3328 . Jika rhitung $>$ rtabel dan nilai positif maka butir pernyataan valid.

\section{b. Reliabilitas}

Uji Reliabilitas adalah alat untuk mengukur suatu kuesioner yang merupakan indikator dari variabel atau konstruk. Suatu koesioner dikatakan reliabel atau handal jika jawaban seseorang terhadap pernyataan adalah konsisten dari waktu kewaktu yaitu jika nilai Cronbach Alpha $(\alpha)>0,6$.

2. Uji asumsi klasik

\section{c. Uji Normalitas}

Uji normalitas bertujuan untuk menguji apakah dalam model regresi, variabel penggangu atau residual memiliki distribusi normal. Pada prinsipnya normalitas dapat dideteksi jika data menyebar disekitar garis diagonal dan mengikuti arah garis diagonal atau grafik histogram menunjukan pola distribusi normal, maka model regresi memenuhi asumsi normalitas.

d. Uji Multikolinearitas

Uji mutikolinearitas bertujuan untuk menguji apakah model regresi ditemukan adanya korelasi antar variabel bebas. Model regresi yang baik seharusnya tidak terjadi korelasi antar variabel independen (ortogonal). Korelasi dapat dikatakan ortogonal atau tidak terjadi korelasi antar variabel bebas jika nilai Tolerance $\geq 0,10$ atau sama dengan nilai VIF $\leq 10$.

e. UJi Heteroskedastisitas

Uji Dari hasil uji residual plot yang terjadi tidak menggambarkan pola tertentu yang sistematis, lebih bersifat acak dan berada diatas serta dibawah nol pada sumbu $Y$, maka persamaan regresi yang dipakai dalam penelitian ini dapat memenuhi asumsi homoskedastisitas atau tidak ada masalah heteroskedastisitas. Cara lainnya yaitu dengan metode Glejser dengan cara meregres nilai absolute 
Maimunah, Pengaruh Kompentensi Sumber Daya Manusia ,Penerapan Sistem Akuntansi Daerah Dan Pemanfaatan Teknologi Informasi Terhadap Kualitas Laporan Keuangan Pemerintah Daerah (Studi Pada SKPD Kabupaten Lumajang)

residualnya terhadap variabel independent, apabila variabel independent signifikan secara statistik mempengaruhi variabel dependent, maka indikasi terjadi heteroskedastisitas. Hal ini terlihat dari probabilitas signifikansinya diatas tingkat kepercayaan 5\% $(0,05)$. Jika dapat disimpulkan model regresi tidak mengandung adanya heteroskedastisitas.

3. Regresi Linier Berganda

persamaan regresi tersebut, dapat disusun persamaan regresi yaitu :

$$
\mathrm{Y}=8,197+0,575 \mathrm{X}_{1}-0,049 \mathrm{X}_{2}+1,575 \mathrm{X}_{3}+3,473
$$

a) Konstanta sebesar 8,197 artinya jika variabel kualitas Laporan Keuangan tidak dipengaruhi oleh ketiga variabel bebas (Kompetensi SDM, Penerapan SAKD dan Pemanfaatan Teknologi) maka Kualitas Laporan Keuangan bernilai konstan

b) Koefisien Kompetensi SDM sebesar 0,575 . hal ini menyatakan bahwa setiap satuan variabel kompetensi sumber daya manusia akan berpengaruh terhadap Kualitas Laporan Keuangan Pemerintah Daerah

c) Koefisien Penerapan SAKD sebesar 0.049. hal ini menyatakan bahwa setiap satuan variabel penerapan SAKD akan berpengaruh terhadap Kualitas Laporan Keuangan Pemerintah

d) Koefisien Pemanfaatan Teknologi Informasi sebesar 1,575 . hal ini menyatakan bahwa setiap variabel pemanfaatan teknologi informasi akan berpengaruh terhadap Kualitas Laporan Keuangan Pemerintah Daerah

e) Error term (e) sebesar 3,473 yang artinya setiap peningkatan (penambahan) terhadap Kualitas Laporan Keuangan selain dipengaruhi oleh variabel Kompetensi SDM,Penerapan SAKDdan Pemanfaatan Teknologi Informasi ternyata juga dipengaruhi oleh variabel lain

4. Uji Hipotesis

f. Uji t (Parsial)

Uji statistik $\mathrm{t}$ atau biasa disebut pengaruh individu dari variabel besas terhadap variabel terikat dilakukan untuk mengetahui pengaruh Kompetensi SDM, Penerapan SAKD dan pemanfaatan teknologi informasi terhadap Kualitas Laporan Keuangan secara individual dalam menerangkan variasi variabel dependen. Pengujian t yang dikukan menggunakan tingkat signifikan $\alpha=0,05$ dengan jumlah sampel $(n)=59$ dan variabel bebas yang digunakan $(\mathrm{k})=2$, degree of freedom $(\mathrm{df})$ yang dihasilkan adalah $\mathrm{df}=\mathrm{n}-\mathrm{k}-1=59-2-1=56$. Sehingga hasil ttabel yang diperoleh adalah 2,001 . Ketentuan yang digunakan adalah jika thitung $>$ ttabel maka variabel berpengaruh secara signifikan dan hipotesis diterima. Maka pengelolaannya diuraikan sebagai berikut:

1) Kompetensi SDM $\left(X_{1}\right)$

Nilai thitung Kompetensi SDM kerja $\left(\mathrm{X}_{1}\right)$ adalah 3,211> ttabel 2,001 dan sig.,002< sig.0,05 sehingga dapat disimpulkan bahwa variabel kompentensi SDM berpengaruh positif dan signifikan terhadap Kualitas Laporan Keuangan artinya bahwa hipotesis 1 diterima.

2) Penerapan $\operatorname{SAKD}\left(\mathrm{X}_{2}\right)$

Nilai thitung Penerapan SAKD $\left(\mathrm{X}_{2}\right)$ adalah $-522>$ ttabel 2,001 dan sig.0,000< sig.604 sehingga dapat disimpulkan bahwa variabel Penerapan SAKD 
Maimunah, Pengaruh Kompentensi Sumber Daya Manusia ,Penerapan Sistem Akuntansi Daerah Dan Pemanfaatan Teknologi Informasi Terhadap Kualitas Laporan Keuangan Pemerintah Daerah (Studi Pada SKPD Kabupaten Lumajang)

berpengaruh negatif dan tidak signifikan terhadap Kualitas Laporan Keuangan artinya bahwa hipotesis 2 ditolak

3) Pemanfaatan teknologi informasi $\left(X_{3}\right)$

Nilai thitung Pemanfaatan teknologi informasi $\left(X_{3}\right)$ adalah 4,678 >tabel 2,001 dan sig.0,000< sig.000 sehingga dapat disimpulkan bahwa variabel Pemanfaatan teknologi berpengaruh positif dan signifikan terhadap Kualitas Laporan Keuangan artinya bahwa hipotesis 3 diterima.

\section{Hasil Uji Koefisien Dterminasi}

Dari tabel di atas dapat disimpulkan koefisien determinasi $R^{2}$ adalah sebesar $673 \%$ artinya sumbangan variabel Kompetensi SDM , Penerapan SAKD dan pemanfaatan teknologi informasi terhadap Kualitas Laporan Keuangan sebesar 67,3\% sedangkan sisanya $32,7 \%(100 \%-67,3 \%)$ variabel lain yang tidak dibahas dalam penelitian ini.

6. Uji Hipotesi Simultan (Uji F)

Uji hipotesis secara serempak untuk mengetahui pengaruh variable independen secara keseluruhan terhadap variable dependen . uji ini di lakukan dengan membandingkan nilai $F$ hitung denga nilai $F$ tabel . nilai $f$ hitung dari hasil pengelolahan data dengan program SPSS dapat di lihat pada hasil uji analisis regresi linear berganda yaitu tabel ANOVA

Dari hasil perhitungan statistik menunjukkan Fhitung sebesar 37,721 dengan sig. $\mathrm{F}=0,00$ dan Ftabel=2,77. Sehingga dapat ditarik kesimpulan Fhitung $>$ Ftabel sehingga Kompetensi SDM ,Penerapan SAKD dan pemanfaatan teknologi informasi secara bersama-sama ber pengaruh positif dan signifikan terhadap kualitas laporan keuangan daerah pada SKPD Kabupaten Lumajang . Artinya bahwa hipotesis 3 diterima.

\section{F. PEMBAHASAN}

1. Hipotesi Pengaruh Kompentensi Sumberdaya Manusia Terhadap Kualitas Laporan Keuangan Pemerintah Daerah

Hipotesis pertama (H1) yang menyebutkan bahwa kompentensi sumber daya manusia berpengaruh positif dan signifikan terhadap kualitas laporan keuangan pemerintah, hasil penelitian didukung oleh data analisis statistik atau dengan kata lain hipotesis di terima .

2.Hipotesis Pengaruh penerapan sistem akuntansi daerah Terhadap Kualitas Laporan Keuangan Pemerintah Daerah

Hipotesis pertama (H2) yang menyebutkan bahwa penerapan sistem akuntansi daerah berpengaruh negatif dan tidak signifikan terhadap kualitas laporan keuangan pemerintah, hasil peneliti di dukung oleh data analisis statistik atau dengan kata lain hipotesis di terima . Mardiasmo (2004) mengatakan bahwa untuk menghasilkan laporan keuangan yang relevanm, Handal, dan dapat dipercaya, pemerintah daerah harus memiliki sistem akuntansi yang handal. Sistem akuntansi yang lemah menyebabkan laporan keuangan yang dihasilkan juga kurang handal dan kurang relevan untuk mengambil keputusan. Oleh karena itu untuk mendapatkan laporan keuangan yang berkualitas diperlukan penerapan sistem akuntansi keuangan daerah yang baik

3. Pengaruh Pemanfaatan Teknologi Informasi Terhadap Kualitas Laporan Keuangan Pemerintah Daerah 
Maimunah, Pengaruh Kompentensi Sumber Daya Manusia ,Penerapan Sistem Akuntansi Daerah Dan Pemanfaatan Teknologi Informasi Terhadap Kualitas Laporan Keuangan Pemerintah Daerah (Studi Pada SKPD Kabupaten Lumajang)

Hipotesis pertama (H3) yang menyebutkan bahwa pemanfaatn teknologi informasi berpengaruhpositif dan signifikan terhadap kualitas laporan keuangan pemerintah , penelitian didukung oleh data analisis statistik atau dengan kata lain hipotesis di terima. Dengan kemajuan teknologi informasi yang pesat serta potensi pemanfaatanya secara luas, maka dapat membuka peluang berbagai pihak untuk mengakses, mengelola dan mendayagunakan informasi keuangan daerah secara cepat dan akurat (Arfianti, 2011). Pemanfaatan teknologi informasi yang baik, diharapkan dapat menghasilkan laporan keuangan yang berkualitas

\section{Hipotesi Pengaruh Kompentensi Sumber Daya Manusia , Penerapan Sistem Akuntansi Daerah Dan Pemanfaatan Teknologi Informasi Terhadap Kualitas Laporan Keuangan Pemerintah Daerah}

Berdasarkan uji regresi secara simultan , Kualitas Sumberdaya Manusia, Penerapan Sistem Akuntansi Daerah Dan Pemanfaatan Teknologi Informasi . hasil dari uji statistik pengaruh tersebut cukup besar yaitu $67 \%$ sedangkan sisanya sebesar 32\% di pengaruhi oleh faktor lain dari penelitian.

\section{G. KESIMPULAN DAN SARAN}

\section{Kesimpulan}

Penelitian ini mengambil tema tentang pengaruh kompetensi sumber daya manusia, penerapan sistem akuntansi daerah dan pemanfaatan teknologi informasi terhadap kualitas laporan keuangan pemerintah daerah.Ada pengaruh yang singnifikan dan simultan dari Kompentensi Sumberdaya Manusia ,Penerapan Sistem Akuntansi Daerah Dan Pemanfaatan Teknologi Informasi Terhadap Kualitas Laporan Keuangan Pemerintah Daerah. jika kompentensi sumber daya manusia tersebut kompenten seperti jumlah yang cukup serta nemiliki latar pendidikan akuntansi sehingga menghasilkan laporan keuangan yang handal, relevan, dapat dipahami dan dipercaya, dan penerapan sistem akuntansi daerah yang sesuai dan di bantu dengan pemanfaatan teknologi informasi sehingga penyajian laporan keuangan pemerintah Kabupaten Lumajang akan semakin berkualitas

\section{Saran}

Berdasarkan hasil penelitian yang telah dilakukan, ada beberapa saran yang dapat dipertimbangkan oleh beberapa pihak, yaitu:

1. Peneliti berikutnya dapat memperluas objek penelitian, misalnya dengan mengambil sampel pada SKPD yang ada dibeberapa kabupaten atau bahkan se-Provinsi.

2. Peneliti berikutnya dapat lebih maksimal dalam memperoleh data kuesioner. Peneliti berikutnya dapat menambahkan variabel lain yang memungkinkan dalam mempengaruhi kualitas laporan keuangan pemerintah daerah.

\section{DAFTAR PUSTAKA}

DediNordiawan (2006:35). Pengertianakuntansisektor public. Jakarta salemba 4

Lillrank., 2003. The quality fg information. Infotmation journal of quality \& reliability management vol. 20 No. 6 pp. 691-703 
Maimunah, Pengaruh Kompentensi Sumber Daya Manusia ,Penerapan Sistem Akuntansi Daerah Dan Pemanfaatan Teknologi Informasi Terhadap Kualitas Laporan Keuangan

Pemerintah Daerah (Studi Pada SKPD Kabupaten Lumajang)

Mardiasmo (2004)pengertian akuntabilitas publik. Penerbit Andi. Yogyakarta

Tjipto herijanto (2001) dalam Alim budiono \& Fidelis (2004), menilai kapasitas dan kompetensi sumber daya manusia.Jurnal akutansi keuangan sektor publik. Vol. 05 No.02 Hal 18-30

Mardiasmo, (2002: 146), sumber daya manusia. Penerbit Andi, Yogyakarta

Permendagri. (Nomor 71 Tahun 2010).PengertianSistemAkuntansiKeuangan Daerah (SAKD)

Halim, Abdul, (2008:35).Devinisi Akutansi Keuangan Daerah. Penerbit salemba 4 jakarta.

Katin wilda maysaroh.(2018) Pengaruh Kompetensi Sumber Daya Mausia, Penerapan Sistem Pengendalian Intern, Penerapan Akutansi Pemerintah, Pemanfaatan Teknologi Informasi Terhadap Kualitas Laporan Keuangan. (study kasus SKPD kabupaten sukoharjo). Skripsi universitas muhammadiyah surakarta.

DzulfikarAhliFikri.2016.pengaruh kompentensi sumber daya manusia, penerapan sistem pngendalian intern pemerintah dan standar akuntansi pemerintah terhadap kualitas laporan keuangan pemerintah daerah.(study kasus SKPD kota Malang). Skripsi universitas kanjuruhan malang.

Nurillah. (2014) pengaruh kompentensi sumber daya manusia, penerapan sistem akuntansi keuangan daerah (SAKD) pemanfaatan teknologi informasi dan sistem pengendalian intren terhadap kualitas laporan keuangan pemerintah daerah. (study empiris pada SKPD kota depok) Skripsi progam sarjana fakultas ekonomika dan bisnis universitas diponegoro.

Sumiati (2012) Pengaruh penerapan sistem akutansi pemerintah daerah (SKPD), akuntabilitas keuangan, ketaatan peraruran perundangan terhadap akuntabilitas kinerja instansi pemerintah daerah.

Zuliarti (2012) Pengaruh nilai informasi pelaporan keuangan, sumber dayamanusia, dan sistem pengendalian intern terhadap teknologi informasi.

Roviyantie (2011) pengaruh kopetensi sumber daya manusia dan keuangan daerah terhadap kualitas laporan keuangan jurnal universitas siliwangi.

Permendangri No. 56 Tahun 2005 tentang Sistem Informasi Keuangan Daerah

Sugiyono, (2002) metode penelitian bisnis, Bandung : alfabeta

Hamzah, (2009) pengertian Pemanfaatan teknologi informasi.Seminar nasional aplikasi teknologi informasi. Yogyakarta

Sugiyono, (2007: 107) metode penelitian bisnis. Bandung : alfabeta

Sastradipoera, (2005) penegertian Validitas. Bandung : Kappa Sigma

Harrison, dalam Zulganef, (2006) pengertian Reliabilitas. Bandung : Pustaka

Ardi Hamzah . (2009) evaluasi kesesuaian model keperilakuandalam penggunaan teknologi informasi di indonesia .seminar nasional aplikasi teknologi informasi . yogyakarta

Suprapto,j (2000) statistik teori dan aplikasi jilid 1edisi 6 erlangga: jakarta 
Maimunah, Pengaruh Kompentensi Sumber Daya Manusia ,Penerapan Sistem Akuntansi Daerah Dan Pemanfaatan Teknologi Informasi Terhadap Kualitas Laporan Keuangan Pemerintah Daerah (Studi Pada SKPD Kabupaten Lumajang)

Ghozali , imam .(2005). Aplikasi analisis multivarieate dengan SPSS. Semarang ;badan penerbit UNDIP

Ghozali , imam .(2009). Aplikasi analisis multivarieate dengan SPSS. Semarang ;badan penerbit UNDIP

Ghozali , imam .(2001). Aplikasi analisis multivarieate dengan SPSS. Semarang ;badan penerbit UNDIP

(http://www.informatika.lipi.go.id/perkembangan-teknologi-informasi-di-indonesia).

(http://.m.jatimtimes.com) 